\title{
Pengaruh Efisiensi dan Motivasi Kerja terhadap Kinerja Karyawan Melalui Sistem E-Procurement Sebagai Variabel Intervening
}

\author{
Agus Suharyanto $^{1}$, Noer Soetjipto ${ }^{2}$, Djoko Sulistya ${ }^{3}$, \\ ${ }^{1}$ Universitas Muhammadiyah Gresik, Gresik, Indonesia \\ ${ }^{2}$ Komisi B BAPERDA Gerindra, Gresik, Indonesia \\ ${ }^{3}$ Universitas Muhammadiyah Gresik, Gresik, Indonesia \\ 1agus_133@yahoo.com, ${ }^{2}$ noersoetjipto@yahoo.co.id, ${ }^{3}$ djoko.soelistya@ bmks.jiipe.co.id
}

\begin{abstract}
This study aims to determine the benefits after being implemented from the EProcurement system which is part of SAP in the Supply Chain Management (procurement) process at PT. Petrochemical Gresik. After migrating the 2016 Enterprise Resource Plan system and applying the E-Procurement system in 2017, benefits from employee performance, work efficiency and job satisfaction can be seen. This study uses intervening variables, where the E-Procurement system is the variable. From the end of the study, it can be seen that there is an increase in work efficiency, but not so with job satisfaction.
\end{abstract}

Keywords: E-Procurement, efficiency, performance, job satisfaction, intervening

\begin{abstract}
ABSTRAK
Penelitian ini bertujuan untuk mengetahui manfaat setelah diimplementasikan dari sistem E-Procurement yang merupakan bagian dari SAP dalam proses Supply Chain Management (procurement) pada perusahaan PT. Petrokimia Gresik. Setelah melakukan migrasi sistem Enterprise Resource Plan tahun 2016 dan mengaplikasikan sistem E-Procurement pada tahun 2017, dapat dilihat manfaat dari kinerja karyawan, efisiensi kerja dan kepuasan kerja. Penelitian ini menggunakan variabel intervening, dimana sistem E-Procurement merupakan variabel tersebut. Dari akhir penelitian dapat dilihat terdapat peningkatan dari efisiensi kerja, namun tidak demikian dengan kepuasan kerja.
\end{abstract}

Kata Kunci: E-Procurement, efisiensi, kinerja, kepuasan kerja, intervening

\section{PENDAHULUAN}

Problematika yang sering terjadi adalah semakin banyak pabrik dibangun, atau diperluas, namun Kompartemen Pengadaan belum mendapat ijin dari Manajemen SDM PT. Petrokimia Gresik untuk penambahan tenaga organik, sedangkan sebagian besar sumber daya manusia di Kompartemen
Pengadaan sudah mulai memasuki masa pensiun untuk beberapa tahun yang akan datang, belum lagi ditambah permasalahan alih teknologi untuk migrasi perangkat lunak yang digunakan perusahaan, yaitu perangkat lunak $S A P$.

Selain permasalahan di atas, dapat dilihat pekerjaan dalam kompartemen pengadaan cukup tinggi 
dibandingkan dengan proses bisnis lainnya,serta membutuhkan kecepatan dalam proses pengerjaannya. Sedangkan, dalam Supply Chain Management terdapat faktor optimalisasi yang harus dikedepankan antara biaya, mutu dan waktu. Ketiga aspek ini harus melekat di dalam proses bisnis pengadaan.

Tabel Data Nilai PO Tahun 2017

\begin{tabular}{|l|c|c|c|c|c|c|}
\hline \multirow{2}{*}{$\begin{array}{c}\text { BULAN } \\
\text { 2017 }\end{array}$} & \multicolumn{7}{|c|}{ ITEM } & \multicolumn{2}{c|}{ Nilai } & $\begin{array}{c}\text { Persentase } \\
\text { Item (\%) }\end{array}$ & $\begin{array}{c}\text { Persentase } \\
\text { Nilai (\%) }\end{array}$ \\
\cline { 2 - 5 } & Total & E-Pro & Total & E-Pro & 8,17 & 0,70 \\
\hline Januari & 1.566 & 128 & 319,88 & 2,23 & 11,89 & 0,41 \\
\hline Februari & 841 & 100 & 356,02 & 1,47 & 46,50 & 4,75 \\
\hline Maret & 1.099 & 511 & 328,69 & 15,61 & 47,95 & 3,44 \\
\hline April & 974 & 467 & 439,89 & 15,11 & 29,23 & 1,88 \\
\hline Mei & 1.177 & 344 & 549,16 & 10,30 & 5,55 & 0.39 \\
\hline Juni & 1.819 & 101 & 451,20 & 1,75 & 49,30 & 6,29 \\
\hline Juli & 1.505 & 742 & 491,53 & 30,90 & 18,17 & 11,20 \\
\hline Agustus & 2.703 & 491 & 412,28 & 46,18 & 26,99 & 3,19 \\
\hline September & 1.293 & 349 & 250,89 & 7,99 & 2,11 & 5,03 \\
\hline Oktober & 1.698 & 698 & 501,78 & 25,25 & 41,11 & 4,47 \\
\hline November & 2.814 & 647 & 680,32 & 30,39 & 22,99 & 3,62 \\
\hline Desember & 2.013 & 471 & 517,25 & 18,72 & 23,40 & 3,89 \\
\hline TOTAL & 19.502 & 5.049 & 5.298 .89 & 205,90 & 25,89 & \\
\hline
\end{tabular}

Dari data laporan kinerja pengadaan, terlihat waktu proses untuk melakukan pembelian cukup lama, waktu yang lama ini jika tidak dilakukan efisiensi dapat berakibat pada pabrik trip, cut rate, atau shutdown, material yang dibutuhkan tidak datang pada waktunya.

Faktor usia tenaga organik di Kompartemen Pengadaan semakin banyak memasuki masa pensiun, banyak faktor kepuasan kerja yang mempengaruhi, ditambah lagi dengan adanya teknologi industri teknologi informasi dalam sistem Supply Chain Management (E-Procurement) hal ini akan menambah faktor kepuasan ini semakin diperhitungkan untuk diteliti.

Pada prinsipnya perangkat lunak sistem E-Procurement merupakan pengganti modul CRM (Customer Relationship Module) pada SAP, sistem E-Procurement mempunyai fungsi dan fitur yang sama, namun sistem E-Procurement merupakan buatan dari implementator SAP, yaitu Abyor, bukan default program dari SAP.Sistem perangkat E-Procurement layaknya modul CRM merupakan modul yang melekat pada SAP, walaupun dibuat secara customize.

Selain itu, dapat dilihat juga perihal adanya penambahan perangkat sistem E-Procurement ini apakah akan menambah atau membantu kinerja tenaga organik Kompartemen Pengadaan, dengan adaya sistem ini secara keseluruhan kinerja tenaga organik apakah semakin meningkat atau kah sebaliknya.

Dalam penelitian ini bertujuan untuk melihat pengaruh sistem $E$ Procurement, efisiensi kerja, kepuasan kerja terhadap kinerja karyawan dalam Kompartemen Pengadaan Petrokimia Gresik. 


\section{LITERATURE REVIEW Manajemen Kinerja}

Amstrong \& Baron

mengatakan bahwa manajemen kinerja merupakan suatu pendekatan strategis dan terintegrasi guna mencapai kesuksesan dalam organisasi dengan cara memperbaiki kinerja para karyawan serta mengembangkan kapabilitas tim dan kontribusi individual. Manajemen kinerja merupakan suatu pendekatan guna menciptakan shared vision akan maksud dan tujuan dari organisasi, membantu setiap karyawan untuk mengerti dan mengenali besarnya kontribusi mereka, sehingga bisa meningkatkan kinerja, baik individual maupun organisasi.

\section{Efisiensi Kerja}

Pengertian efisiensi kerja menurut penulis adalah perbandingan tingkat kerja karyawan suatu perusahaan/badan dibandingkan ukuran referensi tingkat kerja yang sudah dinormalisasikan atau distandarkan. Sedangkan pengertian efisiensi dari Miraza (2004:87) merupakan bentuk pemakaian biaya ataupun lainnya dari setiap komponen pada setiap kegiatan usaha (kerja) yang berjalan secara normal. Komponen yang dimaksud di atas dapat meliputi biaya, waktu dan tenaga kerja. Pada prinsipnya, efisiensi diartikan bagaimana sebuah organisasi/ badan/ perusahaan dalam mencapai tujuannya dengan hasil yang semaksimal mungkin dengan mengeluarkan biaya yang seminimal mungkin.

Syamsi (2004:2) efisiensi berarti sebagai daya guna/hasil, dapat juga diartikan juga daya guna untukbmencapai tujuan/hasil, namun tidak terjadi pemborosan. Dari Menurut Sedarmayanti (2001:11) efisiensi kerja adalah perbandingan terbaik antara ukuran suatu pekerjaan yang dilakukan dengan ukuran hasil yang dicapai oleh pekerjaan tersebut sesuai dengan yang ditargetkan baik dalam hal mutu maupun hasilnya yang meliputi pemakaian waktu yang optimal dan kualitas cara kerja yang maksimal.

\section{Kepuasan Kerja}

Kepuasan kerja menurut pendapat dari Hasibuan (2001:202), sikap emosional karyawan/pekerja yang menandakan mencintai pekerjaannya dan merasa menyenangkan, perilaku ini dapat dilihat dari karyawan dalam sikapnya dalam pekerjaan, selepas pekerjaan, atau pun kombinasi keduanya. Sikap ini dapat ditunjukkan dengan moral kerja, kedisplinan, dan prestasi kerja, ketiga hal ini kemudian dapat menimbulkan kepuasan kerja, kepuasan ini juga dapat dilihat dari sifat dan jenis pekerjaan yang harus dilakukan sesuai dengan kebutuhan (target) dan nilai yang dimiliki.

Davis (1995:105) berpendapat dalam tulisannya, kepuasan kerja merupakan kepuasan karyawan terhadap hasil pekerjaannya, antara apa yang diharapkan dari karyawan terhadap pekerjaan/perusahaannya. Dapat diambil kesimpulan bahwa kepuasan kerja intinya akan didapat jika tingkat kepuasan yang berbeda akan sesuai dengan sistem nilai yang tertanam pada dirinya.

\section{METODE PENELITIAN Populasi}

Dari pemikirannya Sugiyono (2013:117), populasi merupakan tempat atau wilayah yang digeneralisasi dimana terdapat objek atau subjek yang mempunyai kualitas dan karakteristik tertentu yang ditetapkan oleh peneliti untuk dikaji 
kemudian ditarik kesimpulan. Menurut pemikiran Arikunto (2012:104) jika populasi berjumlah kurang dari 100 orang, maka total sampelnya diambil secara keseluruhan, namun jika jumlah

populasi lebih besar dari 100 orang, maka dapat diambil sebesar $10-15 \%$ atau 20-25\% dari total jumlah populasinya. Rincian responden yang diambil untuk survei yaitu :

Tabel List Responden Kuisioner

\begin{tabular}{|c|l|c|l|l|}
\hline No. & Departemen & Bagian & Jumlah Responden & Keterangan \\
\hline 1 & Pengadaan Barang & A & 4 responden & 1 Sarjana, 3 SLTA \\
\hline 2 & Pengadaan Barang & B & 5 responden & 1 Sarjana, 4 SLTA \\
\hline 3 & Pengadaan Barang & C & 3 responden & 3 SLTA \\
\hline 4 & Pengadaan Jasa & D & 4 responden & 1 Sarjana, 1 D3, 2 SLTA \\
\hline 5 & Pengadaan Jasa & E & 3 responden & 1 Sarjana, 1 D3, 1 SLTA \\
\hline 6 & Pengadaan Jasa & F & 2 responden & 1 D3, 1 SLTA \\
\hline & & TOTAL & 21 repsonden & \\
\hline
\end{tabular}

\section{Variabel Penelitian}

Dari Nur Indriantoro, \& Bambang Supomo (2001), variabel intervening merupakan tipe variabel-variabel yang mempengaruhi hubungan antara variabel independen dengan variabel dependen menjadi hubungan secara tidak langsung. Dari penjelasan sebelumnya diagaram analisa jalur sebagai berikut:

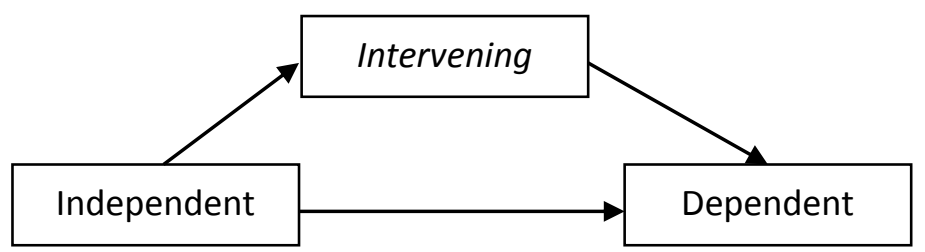

Gambar Skema variabel

Keterangan:

Variabel intervening : sistem E-Procurement

Variabel dependent : kinerja Karyawan

Variabel independent : efisiensi kerja, kepuasan kerja

Pada kuesioner, akan terdapat respon atau jawaban dari para responden, dan dari jawaban responden ini dengan skala Likert, maka variabel yang akan diukur dijabarkan akan menjadi indikator variabel. Berikut tabel yang secara umum menggambarkan respon atau pernyataan dari responder. Untuk lebih jelasnya, dapat dijelaskan dari tabel berikut dibawah ini, dimana terdapat penjelasan untuk variabel, indikator, dan skala pengukuran untuk penelitian ini.

Tabel Variabel Independent, Dependent, dan Intervening

\begin{tabular}{|c|c|c|c|}
\hline No. & Variabel & Indikator & Pengukuran \\
\hline 1. & $\begin{array}{l}\text { Variabel } \\
\text { intervening: } \\
\text { Sistem } E \text { - } \\
\text { Procurement }\end{array}$ & $\begin{array}{l}\text { A1 : } \\
\text { kehandalan sistem E-Proc. sistem E-Proc bekerja } \\
\text { handal atau tidak } \\
\text { A2 : informasi akurat sistem E-Proc menyediakan } \\
\text { informasi yang akurat } \\
\text { A } 3 \text { : fitur memudahkan sistem E-Proc memudahkahkan } \\
\\
\text { dalam bekerja (Armstrong \& Baron, Costello ; } \\
\text { manajemen kinerja) }\end{array}$ & $\begin{array}{l}\text { Skala } 1 \text { s/d } 5 \\
\text { dari Sangat } \\
\text { Setuju sampai } \\
\text { Tidak Setuju }\end{array}$ \\
\hline
\end{tabular}




\begin{tabular}{|c|c|c|c|}
\hline No. & Variabel & Indikator & Pengukuran \\
\hline 2. & $\begin{array}{l}\text { Variabel } \\
\text { dependent : } \\
\text { kinerja } \\
\text { karyawan }\end{array}$ & 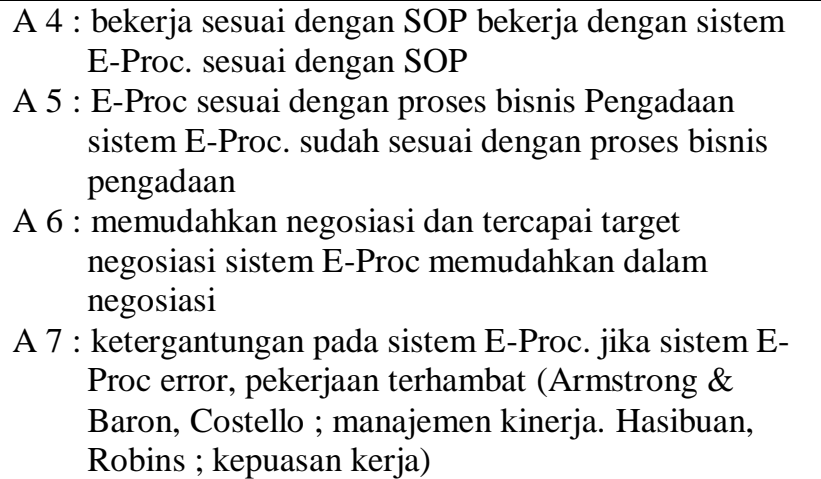 & $\begin{array}{l}\text { Skala } 1 \text { s/d } 5 \\
\text { dari Sangat } \\
\text { Setuju sampai } \\
\text { Tidak Setuju }\end{array}$ \\
\hline 3. & $\begin{array}{l}\text { Variabel } \\
\text { independent } \\
1: \\
\text { efisiensi } \\
\text { kerja }\end{array}$ & $\begin{aligned} \text { A } 8: \text { bekerja lebih mudah bekerja dengan sistem E-Proc. } \\
\text { menjadi lebih mudah } \\
\text { A } 9: \text { E-Proc menyingkat waktu pekerjaan bekerja dengan } \\
\text { sistem E-Proc menghemat waktu dalam bekerja } \\
\text { A } 10: \text { E-Proc lebih membutuhkan sedikit peralatan kerja } \\
\text { sistem E-Proc menghemat peralatan terutama kertas }\end{aligned}$ & $\begin{array}{l}\text { Skala } 1 \text { s/d } 5 \\
\text { dari Sangat } \\
\text { Setuju sampai } \\
\text { Tidak Setuju }\end{array}$ \\
\hline 4. & $\begin{array}{l}\text { Variabel } \\
\text { independent } \\
2: \\
\text { kepuasan } \\
\text { kerja }\end{array}$ & $\begin{array}{l}\text { A } 11: \text { mudah dipelajari sistem E-Proc mudah dipelajari } \\
\text { A } 12: \text { sistem E-Proc lengkap Sistem E-Proc lengkap } \\
\text { untuk pekerjaan sehari-hari } \\
\text { A 13: sistem E-Proc mudah digunakan Sistem E-Proc } \\
\text { mudah digunakan dalam bekerja } \\
\text { A 14: sistem E-Proc sering dan kontinyu digunakan } \\
\text { Sistem E-Proc digunakan dalam fungsi pekerjaan } \\
\text { tiap hari (Miraza, Sedarmayanti ; efisiensi kerja) }\end{array}$ & $\begin{array}{l}\text { Skala } 1 \text { s/d } 5 \\
\text { dari Sangat } \\
\text { Setuju sampai } \\
\text { Tidak Setuju }\end{array}$ \\
\hline
\end{tabular}

\section{Metoda Analisa Data Uji Analisa Data}

Dalam penentuan layak atau tidaknya suatu data yang akan digunakan, umumnya dilakukan uji signifikansi koefisien korelasi pada taraf signifikansi sebesar 0,05 . Jika $r$ hitung $\geq \mathrm{r}$ tabel (uji 2 sisi dengan sig. 0,05), maka instrumen atau item-item pertanyaan berkorelasi signifikan terhadap skor total dapat dinyatakan absah/valid. Penelitian ini menggunakan program SPSS.

\section{Uji Reabilitas Data}

Suatu penelitian dianggap dapat diandalkan apabila memberikan hasil yang konsisten untuk pengukuran yang sama, dan tidak bisa diandalkan jika hasil pengukuran yang berulang itu memberikan hasil yang berbeda. Maksudnya menghasilkan yang berbeda ini, pengukuran dapat diandalkan akan mengukur objek secara konsisten, tapi belum tentu mengukur apa yang seharusnya diukur. Seperti halnya yang dikemukakan oleh Walizer (1987) pengertian dari reliabilitas adalah keajegan pengukuran. Suatu kuesioner dikatakan reliabel atau handal jika jawaban seseorang terhadap pernyataan adalah konsisten atau stabil dari waktu ke waktu. Reliabilitas suatu test merujuk pada derajat stabilitas, konsistensi, daya prediksi, dan akurasi.

Pengujian reliabilitas instrumen dengan menggunakan rumus Alpha Cronbach karena instrumen penelitian ini berbentuk angket dan skala bertingkat. Rumus Alpha Cronbach sebagai berikut : 


$$
r_{11}=\left(\frac{n}{n-1}\right)\left(1-\frac{\sum \sigma_{t}^{2}}{\sigma_{t}^{2}}\right)
$$

Keterangan :

$\mathrm{r} 11=$ realibilitas yang dicari

$\mathrm{n} \quad=$ jumlah item pertanyaan yangdiuji

$\sum$ ờt2 $=$ jumlah varians skor tiap-tiap item

ơt2 $=$ varians total

Jika nilai alpha $>0.7$ berarti reliabilitas mencukupi (sufficient reliability) sementara jika alpha $>0.80$ ini berarti seluruh item reliabel dan seluruh tes secara konsisten memiliki reliabilitas yang kuat. Atau, ada pula yang mengartikannya bahwa jika alpha $>0.90$ berarti reliabilitas sempurna. Jika alpha antara $0.70-$ 0.90 berarti reliabilitas tinggi. Jika alpha $0.50-0.70$ berarti reliabilitas moderat. Jika alpha $<0.50$ berarti reliabilitas rendah. Jika alpha rendah, kemungkinan satu atau beberapa item tidak reliabel.

\section{Uji Hipotesa Data}

Suatu penelitian, terdapat adanya hipotesa, dan pengujian hipotesa sangat penting dan harus dilakukan. Pengujian hipotesis pada penelitian ini dilakukan dengan pendekatan model analisis satu jalur atau dikenal dengan path analysis. Metode path analysis ini dikenal dengan 4 (empat) jenis, yaitu analis regresi berganda, regresi parsial, korelasi berganda dan korelasi parsial. Sedangkan untuk pengolahan data penelitian menggunakan program
Statistical Product and Service Solution (SPSS).

Metode yang sering digunakan berdasarkan pendapat dari Supardi (2011:231) adalah metoda regresi linear berganda, yaitu beberapa variabel bebas (X1), (X2) dan (Xn) yang merupakan bagian dari analisis multivariate dengan tujuan untuk menduga besarnya koefisien regresi yang akan menunjukkan besarnya pengaruh beberapa variabel bebas/independent terhadap variabel tidak bebas/dependent. Dalam perhitungan ini, seluruh variabel bebas akan dimasukkan ke dalam perhitungan regresi secara serentak.

Adapun rumus persamaan regresi linear berganda menurut yang disampaikan Priyatno (2008: 73) adalah sebagai berikut:

$Y=\alpha+\beta_{1} X_{1}+\beta_{2} X_{2}+\ldots+\beta_{n} X_{n}+e$

Dari tulisannya, metoda ini digunakan untuk mengetahui apakah terdapat pengaruh yang cukup besar dari variabel independen (A1, A2, $\mathrm{A} 3, \ldots \mathrm{Xn})$ secara parsial terhadap variabel dependen (Y). Rumus T hitung pada analisis regresi adalah:

Keterangan:

$$
T_{\text {hitung }}=\frac{r \sqrt{n-k-1}}{\sqrt{1-r^{2}}}
$$

$\mathrm{r}=$ Koefisiensi korelasi parsial

$\mathrm{k}=$ Jumlah variabel independen

$\mathrm{n}=$ Jumlah data atau kasus

Tujuan dari metode analisis regresi berganda ini untuk mengetahui adanya hubungan antara dua atau lebih variabel independen $\left(X_{1}, X_{2}, \ldots X_{n}\right)$ terhadap variabel dependen (Y) secara serentak. Hubungan antara variabel independen dengan variabel dependen ditunjukkan dengan nilai koefisien. 
Besarnya koefisien ini menunjukkan seberapa besar hubungan yang terjadi antara variabel independen $(\mathrm{X} 1, \mathrm{X} 2$, ...Xn) secara serentak terhadap variabel dependen (Y). Nilai $R$ berkisar antara 0 sampai 1 , nilai semakin mendekati 1 berarti hubungan yang terjadi semakin kuat, sebaliknya nilai semakin mendekati 0 , maka hubungan akan semakin lemah, seperti yang diterangkan Priyatno $(2008 ; 78)$.

Rumus korelasi ganda dari tiga variabel bebas (X1 dan X2) dengan satu variabel terikat (Y) sebagai berikut

$$
R_{y 123}=\sqrt{\frac{\beta_{1} \sum X_{1} Y+\beta_{2} \sum X_{2} Y+\beta_{3} X_{3} Y+\ldots+\beta_{i} \sum X_{i} Y}{\sum Y^{2}}}
$$

Keterangan:

$$
\begin{array}{ll}
\beta_{i} & =\text { Koefisien regresi masing-masing variabel } \\
R_{y 123} & =\text { Koefisien korelasi ganda masing-masing variabel }
\end{array}
$$

Selain analisis regresi berganda, dibutuhkan juga metoda analisis korelasi parsial. Tujuan dari metoda analisis korelasi parsial ini untuk menjelaskan tentang tingkat keeratan hubungan suatu variabel independent dengan variabel dependent dalam suatu sistem korelasi ganda, setelah mengontrol/ mengendalikan variabel independent lainnya. Seperti yang dikemukankan Supardi (2012:92) contoh korelasi ganda dengan dua variabel bebas dapat ditentukan koefisien korelasi parsial antara X1 dan $\mathrm{Y}$ dengan mengendalikan variabel $\mathrm{X} 2$, dan koefisien korelasi parsial $\mathrm{X} 2$ dan $\mathrm{Y}$ dengan mengendalikan variabel $\mathrm{X} 1$. Rumus korelasi Parsial dengan contoh variabel $\mathrm{X} 1$ dan $\mathrm{Y}$, setelah mengendalikan $X 2$, yaitu:

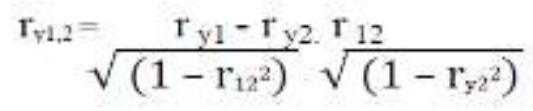

Menurut (Sugiyono, 2007), pedoman untuk memberikan interpretasi koefisien korelasi sebagai berikut:

$$
\begin{aligned}
& 0.00-0.199=\text { sangat rendah } \\
& 0.20-0.399=\text { rendah } \\
& 0.40-0.599=\text { sedang } \\
& 0.60-0.799=\text { kuat } \\
& 0.80-0.999=\text { sangat kuat }
\end{aligned}
$$

Setelah melakukan uji regresi linear berganda dan uji korelasi, perhitungan penelitian ini kemudian melakukan kajian lebih dalam lagi dengan menggunakan ujian Varian Satu Jalur (One Way ANOVA). Menurut Priyanto (2008:12) uji ini digunakan untuk mengetahui ada atau tidaknya perbedaan rata-rata untuk lebih dari dua kelompok sampel yang tidak berhubungan. Jika ada perbedaan, rata-rata manakah yang lebih tinggi. Data yang digunakan biasanya berskala interval/rasi dan data yang memenuhi syarat jika varian sama atau subjek berasal dari kelompok yang homogen.

\section{Kerangka Berpikir}

Robert D. Retherford menyatakan bahwa analisis jalur yaitu suatu teknik dalam menganalisis hubungan sebab-akibat yang terjadi dalam regresi berganda, jika variabel independen mempengaruhi variabel dependen, baik secara langsung dan tidak langsung.

Dari definisi di atas, dapat disimpulkan bahwa analisis jalur merupakan teknik pengembangan regresi linier berganda. Teknik ini 
digunakan untuk menguji besarnya pengaruh (kontribusi) yang ditunjukkan oleh koefisien jalur pada masing-masing diagram jalur hubungan kausal antara variabel A1, A2, A3,... A14 ke Y dan dampak pada Z. Dari perubahan platform sistem ERP dalam perusahaan PT. Petrokimia
Gresik ini akan diteliti, pengaruh sistem E-Procurement terhadap efisiensi kerja, kepuasan kerja dalam meningkatkan kinerja karyawan, terutama yang berkaitan dengan sistem E-Procurement. Berikut digambarkan diagram path analysisnya.

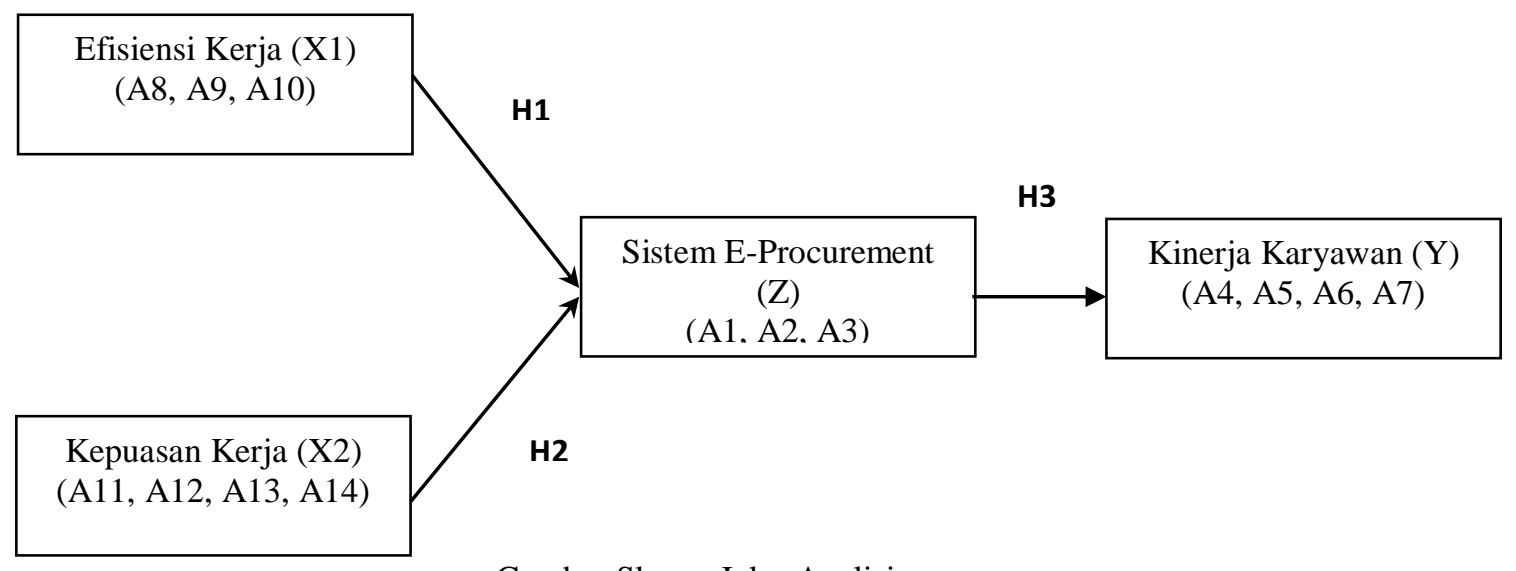

Gambar Skema Jalur Analisis

\section{Hipotesis Penelitian}

Berdasarkan kerangka pemikiran, maka hipotesis yang diajukan adalah sebagai berikut :

1. Hipotesis 1 : Diduga pengaruh efisiensi kerja melalui sistem $E$ Procurement secara parsial terhadap kinerja karyawan cukup besar dalam Kompartemen Pengadaan Petrokimia Gresik

2. Hipotesis 2 : Diduga ada pengaruh kepuasan kerja melalui sistem $E$ Procurement secara parsial terhadap kinerja karyawan cukup besar dalam Kompartemen Pengadaan Petrokimia Gresik
3. Hipotesis 3 : Diduga ada pengaruh sistem E-Procurement secara parsial terhadap kinerja karyawan cukup besar dalam Kompartemen Pengadaan Petrokimia Gresik

\section{Hasil}

\section{Uji Validitas}

Uji coba instrumen telah dilakukan terhadap 21 responden menemukan bahwa semua indikator yang terdapat dalam kuisioner efisiensi kerja, kepuasan kerja, sistem E-Procurement dan kinerja karyawa dapat dinyatakan valid karena semua indikator mempunyai nilai lebih besar dari $\mathrm{r}$ tabel $(0,433)$

Tabel Uji Validitas Variabel Sistem E-Procurement

\begin{tabular}{|c|c|c|c|}
\hline Item & rxy & r tabel & Keterangan \\
\hline A1 & 0,712 & 0,433 & Valid \\
\hline A2 & 0,758 & 0,433 & Valid \\
\hline A3 & 0,785 & 0,433 & Valid \\
\hline
\end{tabular}

Tabel diatas diketahui bahwa memudahkan valid karena nilai rxy keseluruhan variabel sistem $E$ - lebih besar dari rvtabel. Selanjutnya Procurement yang terdiri dari A1 dilakukan uji variabel kinerja kehandalan sistem E-Proc, A2 karyawan yang disajikan pada Tabel informasi akurat, A3 fitur dibawah ini. 
Tabel Uji Validitas Variabel Kinerja Karyawan

\begin{tabular}{|c|c|c|c|}
\hline Item & rxy & rtabel & Keterangan \\
\hline A4 & 0,889 & 0,433 & Valid \\
\hline A5 & 0,678 & 0,433 & Valid \\
\hline A6 & 0,889 & 0,433 & Valid \\
\hline A7 & $-0,231$ & 0,433 & Tidak valid \\
\hline
\end{tabular}

Tabel diatas dapat diketahui bahwa keseluruhan variabel kinerja karyawan yang terdiri dari A4 bekerja sesuai SOP, A5 E-Proc sesuai dengan proses bisnis Pengadaan, A6 memudahkan negosiasi valid karena nilai rxy lebih besar dari rtabel sedangkan untuk variabel A7 ketergantungan pada sistem E-Proc tidak valid karena nilai rxy lebih kecil r tabel. Selanjutnya dilakukan uji variabel efisiensi kerja yang disajikan pada Tabel dibawah ini.

Tabel Uji Validitas Variabel Efisiensi Kerja

\begin{tabular}{|c|c|c|c|}
\hline Item & rxy & rtabel & Keterangan \\
\hline A8 & 0,889 & 0,433 & Valid \\
\hline A9 & 0,678 & 0,433 & Valid \\
\hline A10 & 0,889 & 0,433 & Valid \\
\hline
\end{tabular}

Tabel diatas diketahui bahwa keseluruhan variabel efisiensi kerja yang terdiri dari A8 bekerja lebih mudah, A9 E-Proc menyingkat waktu pekerjaan, A10 E-proc lebih membutuhkan sedikit peralatan kerja valid karena nilai rxy lebih besar dari rtabel. Selanjutnya dilakukan uji variabel kepuasan kerja yang disajikan pada Tabel.

Tabel Uji Validitas Variabel Kepuasan Kerja

\begin{tabular}{|c|c|c|c|}
\hline Item & rxy & rtabel & Keterangan \\
\hline A11 & 0,574 & 0,433 & Valid \\
\hline A12 & 0,776 & 0,433 & Valid \\
\hline A13 & 0,746 & 0,433 & Valid \\
\hline A14 & 0,785 & 0,433 & Valid \\
\hline
\end{tabular}

Tabel diatas diketahui bahwa A13 sistem E-proc mudah digunakan, keseluruhan variabel kepuasan kerja dan A13 sistem E-Proc sering dan yang terdiri dari A11 mudah kontinyu digunakan valid karena nilai dipelajari, A12 sistem E-Proc lengkap, rxy lebih besar dari r tabel.

\section{Uji Realibilitas}

Tabel Uji Reliabilitas

\begin{tabular}{|c|c|c|c|}
\hline Variabel & Nilai Alpha & pembanding & Keterangan \\
\hline Sistem E-proc & 0,804 & 0,60 & Reliabel \\
\hline Kinerja karyawan & 0,842 & 0,60 & Reliabel \\
\hline Efisiensi Kerja & 0,836 & 0,60 & Reliabel \\
\hline Kepuasan Kerja & 0,787 & 0,60 & Reliabel \\
\hline
\end{tabular}

Tabel diatas menunjukkan digunakan sebagai alat ukur dalam bahwa keempat variabel memiliki nilai Alpha lebih besar dari 0,60. Hal ini bermakna bahwa kuisioner sistem E-Procurement, kinerja karyawan, efisiensi kerja dan kepuasan kerja dapat dinyatakan reliabel dan dapat penelitian.

\section{Uji Analisa Jalur}

Analisis Jalur Pengaruh Efisiensi Kerja (X1) dan Kepuasan Kerja (X2) Terhadap Sistem E-Procurement (Z) 
Tabel Analisis Jalur Pengaruh Efisiensi Kerja (X1) dan Kepuasan Kerja (X2)

Terhadap Sistem E-Procurement (Z)

\begin{tabular}{|c|c|c|c|c|c|}
\hline \multirow{2}{*}{ Variabel } & \multicolumn{2}{|c|}{ Unstandarized Coefficients } & \multirow{2}{*}{$\begin{array}{c}\text { Standarized } \\
\text { Coefficients } \\
\text { Beta }\end{array}$} & \multirow[t]{2}{*}{$\mathrm{T}$} & \multirow[t]{2}{*}{ Sig. } \\
\hline & $\mathrm{B}$ & Std.Error & & & \\
\hline Constant & $-1,717$ & 1,717 & & $-1,00$ & 0,331 \\
\hline Efisiensi kerja & 0,469 & 0,141 & 0,526 & 3,328 & 0,004 \\
\hline $\begin{array}{c}\text { Kepuasan } \\
\text { kerja }\end{array}$ & 0,387 & 0,147 & 0,417 & 2,638 & 0,017 \\
\hline
\end{tabular}

Dari Tabel diatas maka persamaan I analisis jalur pada penelitian ini dapat dijabarkan sebagai berikut :

$$
\begin{gathered}
Z=\beta_{1} X_{1}+\beta_{2} X_{2}+e_{1} \\
Z=0,526 X_{1}+0,417 X_{2}+0,534
\end{gathered}
$$

Keterangan :

Nilai 0,534 diperoleh dari

$$
e_{1}=\sqrt{(1-0,715)}=\sqrt{0,285}=0,534
$$

Pada persamaan I dapat dijelaskan sebagai berikut :

Koefisien variabel efisiensi kerja (X1) adalah 0,526 dan bertanda positif artinya setiap perbaikan efisiensi kerja sebesar satu satuan akan meningkatkan sistem E-Procurement

sebesar 0,526 satuan dengan asumsi variabel lainnya dianggap tetap.

Koefisien variabel kepuasan kerja (X2) adalah 0,417 dan bertanda positif artinya setiap perbaikan kepuasan kerja sebesar satu satuan akan meningkatkan sistem $E$ Procurement sebesar 0,417 satuan dengan asumsi variabel lainnya dianggap tetap.

$$
e_{1}=\text { jumlah varian sistem } E \text { - }
$$

Procurement (Z) yang tidak dapat dijelaskan oleh variabel efisiensi kerja (A1) dan kepuasan kerja (A2) adalah 0,534. Analisis Jalur Pengaruh Efisiensi Kerja (X1) dan Kepuasan Kerja (X2) dan Sistem E-Procurement (Z) Terhadap Kinerja Karyawan (Y)

Tabel Analisis Jalur Pengaruh Efisiensi Kerja (X1) dan Kepuasan Kerja (X2) dan Sistem EProcurement (Z) Terhadap Kinerja Karyawan (Y)

\begin{tabular}{|c|c|c|c|c|c|}
\hline \multirow{2}{*}{ Variabel } & \multicolumn{2}{|c|}{ Unstandarized Coefficients } & $\begin{array}{c}\text { Standarized } \\
\text { Coefficients }\end{array}$ & \multirow{2}{*}{$\mathrm{T}$} & \multirow{2}{*}{ Sig. } \\
\cline { 2 - 4 } & $\mathrm{B}$ & Std.Error & Beta & & \\
\hline Constant & 4,417 & 1,548 & & 2,853 & 0,011 \\
\hline Efisiensi kerja & 0,780 & 0,157 & 0,996 & 4,959 & 0,000 \\
\hline $\begin{array}{c}\text { Kepuasan } \\
\text { kerja }\end{array}$ & 0,052 & 0,151 & 0,063 & 0,34 & 0,738 \\
\hline Sistem E-Proc & $-0,215$ & 0,207 & $-0,245$ & 1,040 & 0,313 \\
\hline
\end{tabular}

Dari Tabel diatas maka persamaan II analisis jalur pada penelitian ini dapat dijabarkan sebagai berikut: :

$$
\begin{gathered}
Z=\beta_{1} X_{1}+\beta_{2} X_{2}+\beta_{3} X_{3}+e_{1} \\
Z=0,996 X_{1}+0,063 X_{2}-0,245 X_{3}+0,52
\end{gathered}
$$

Keterangan :

$$
\begin{array}{r}
\text { Nilai } 0,52 \text { diperoleh dari } \\
e_{2}=\sqrt{(1-0,73)}=\sqrt{0,27}=0,52
\end{array}
$$

Pada persamaan I dapat dijelaskan sebagai berikut :

Koefisien variabel efisiensi kerja (X1) adalah 0,996 dan bertanda positif artinya setiap perbaikan efisiensi kerja sebesar satu satuan akan meningkatkan kinerja karyawan (Y) sebesar 0,996 satuan dengan asumsi variabel lainnya dianggap tetap. 
Koefisien variabel kepuasan kerja (X2) adalah 0,063 dan bertanda positif artinya setiap perbaikan kepuasan kerja sebesar satu satuan akan meningkatkan kinerja karyawan (Y) sebesar 0,063 satuan dengan asumsi variabel lain dianggap tetap.

Koefisien variabel sistem $E$ Procurement (Z) adalah 0,063 dan bertanda negatif artinya setiap perbaikan sistem E-Procurement (Z) sebesar satu satuan akan menurunkan kinerja karyawan (Y) sebesar 0,245 satuan dengan asumsi variabel lainnya dianggap tetap.

$$
e_{1}=\text { jumlah varian kinerja }
$$
karyawan (Y) yang tidak dapat dijelaskan oleh variabel efisiensi kerja (X1), kepuasan kerja (X2) dan sistem E-Procurement (Z) adalah 0,52.

\section{Pembahasan \\ Pengujian Hipotesis}

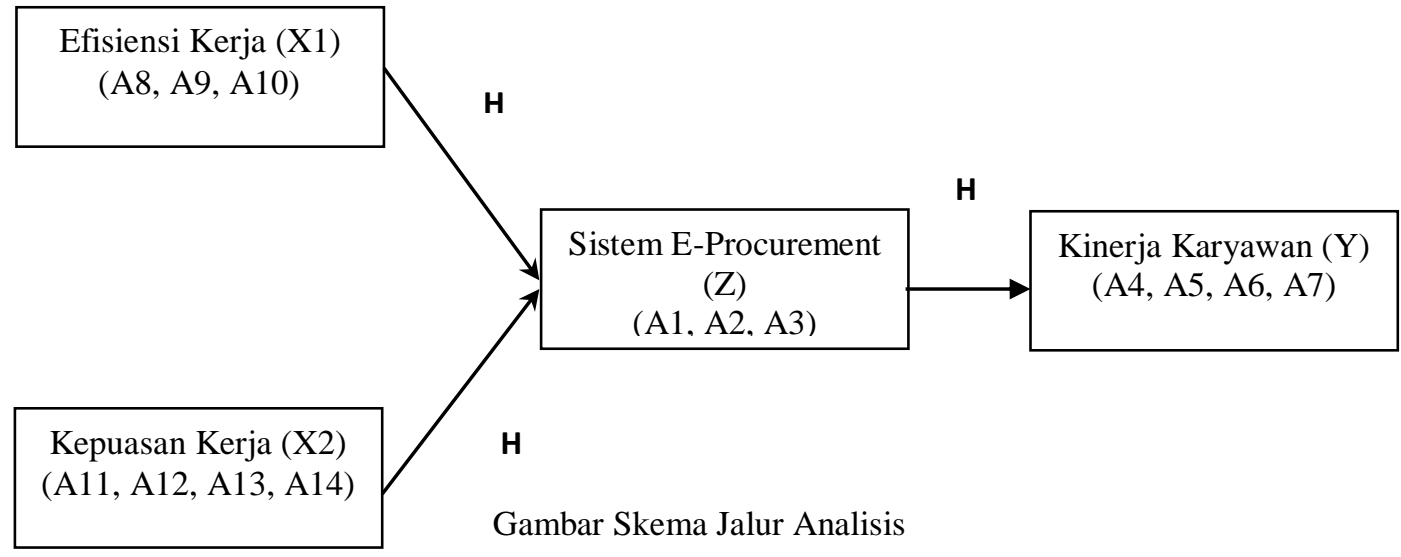

Berdasarkan kerangka pemikiran di atas, maka hipotesis yang diajukan adalah sebagai berikut :

1. Analisa Hipotesis 1 :

Dari data yang diperoleh kemudian diolah menggunakan perangkat lunak SPSS didapatkam bahwa dengan taraf signifikan sebesar 0,05 diperoleh nilai ttabel sebesar 2,11, sedangkan dari perhitungan didapat thitung pada variabel sistem E-Procurement (Z) sebesar 1,040. Maka dapat disimpulkan bahwa thitung < t tabel maka HO gagal ditolak yang berarti koefisien variabel efisiensi kerja (X1) memiliki pengaruh yang tidak signifikan terhadap kinerja karyawan (Y), maka tidak terdapat pengaruh sistem E-Procurement terhadap kinerja karyawan. Jika nilai variabel sistem E-Procurement meningkat maka kinerja karyawan tidak meningkat. Data tersebut menandakan bahwa sistem $E$ -
Procurement mempunyai pengaruh yang cukup kecil terhadap kinerja karyawan, hal ini menandakan bahwa sistem E-Procurement setelah diterapkan sistem E-Procurement tidak cukup signifikan terhadap kinerja karyawan, dalam arti sistem $E$ Procurement dan kinerja karyawan pada Kompartemen Pengadaan tidak berhubungan erat setelah diterapkan sistem E-Procurement . Hal ini dimungkinkan karena sistem EProcurement masih sering terkendala error dari server pusat, walaupun secara efisiensi karyawan meningkat terhadap kinerja karyawan setelah adanya sistem ini, namun tak dapat dipungkiri persepsi karyawan Kompartemen Pengadaan menganggap sistem E-Procurement yang masih terkendala error ini menjadi halangan dan ganjalan dalam pekerjaan sehari-hari, sehingga mempengaruhi dampak persepsi 
karyawan menjadi tidak cukup signifikan.

2. Analisa Hipotesis 2 :

Dari data yang diperoleh kemudian diolah menggunakan perangkat lunak SPSS didapatkam bahwa dari hasil regresi linier diketahui besarnya nilai jalur path $\beta 1 \mathrm{X}_{1} \mathrm{Y}=0,996$, nilai jalur path $\beta_{1} X_{1} Z=0,526$, nilai jalur path $\beta_{3} Z Y=$

Tabel Uji Perbandingan Pengaruh Langsung Pengaruh Tidak Langsung

Variabel Efisiensi Kerja Terhadap Kinerja Karyawan

\begin{tabular}{|c|c|c|c|}
\hline Variabel & Pengaruh langsung (a) & Pengaruh tidak langsung (b) & Hasil \\
\hline Efisiensi kerja & 0,996 & $0,526 \times-0,245=-0,12887$ & a $>\mathrm{b}$ \\
\hline
\end{tabular}

Dengan membandingkan kedua hasil tersebut dapat ditarik kesimpulan bahwa nilai pengaruh langsung variabel efisiensi kerja terhadap kinerja karyawan sebesar 0,996 lebih besar daripada nilai pengaruh tidak langsung variabel efisiensi kerja terhadap kinerja karyawan dengan sistem E-Procurement sebagai variabel intervening. Dengan demikian hipotesis 2 ditolak. Data tersebut menandakan bahwa efisiensi kerja melalui sistem E-Procurement secara parsial tidak mempunyai pengaruh terhadap kinerja karyawan, hal ini menandakan bahwa sistem EProcurement tersebut setelah diterapkan efisiensi kerja melalui sistem E-Procurement secara parsial tidak signifikan terhadap kinerja karyawan. Hal ini dimungkinkan
-0,245 sehingga hasil pengujian pengaruh langsung langsung variabel efisiensi kerja terhadap kinerja karyawan dan pengaruh tidak langsung efisiensi kerja terhadap kinerja karyawan dengan sistem $E$ Procurement sebagai variabel intervening dalam analisis path dapat dilihat pada Tabel berikut. karena sistem E-Procurement masih sering terkendala error dari server pusat, seperti halnya analisa sebelumnya.

\section{Analisa Hipotesis 3 :}

Dari data yang diperoleh kemudian diolah menggunakan perangkat lunak SPSS didapatkam bahwa dari hasil regresi linier diketahui besarnya nilai jalur path $\beta_{2} \mathrm{X}_{2} \mathrm{Y}=0,063$, nilai jalur path $\beta_{2} \mathrm{X}_{2} \mathrm{Z}$ $=0,417$, nilai jalur path $\beta_{3} Z Y=-0,245$ sehingga hasil pengujian pengaruh langsung langsung variabel efisiensi kerja terhadap kinerja karyawan dan pengaruh tidak langsung efisiensi kerja terhadap kinerja karyawan dengan sistem E-Procurement sebagai variabel intervening dalam analisis path dapat dilihat pada Tabel dibawah ini:

Tabel Uji Perbandingan Pengaruh Langsung dan Pengaruh Tidak Langsung

\begin{tabular}{|c|c|c|c|}
\hline Variabel & Pengaruh langsung (a) & Pengaruh tidak langsung (b) & Hasil \\
\hline Kepuasan kerja & 0,063 & $0,417 \times-0,245=-0,102165$ & $\mathrm{a}>\mathrm{b}$ \\
\hline
\end{tabular}

Dengan membandingkan kedua hasil Tabel diatas ditarik kesimpulan bahwa nilai pengaruh langsung variabel kepuasan kerja terhadap kinerja karyawan sebesar 0,063 lebih besar daripada nilai pengaruh tidak langsung variabel efisiensi kerja terhadap kinerja karyawan dengan sistem E-Procurement sebagai variabel intervening. Dengan demikian hipotesis 3 ditolak. Data tersebut menandakan bahwa kepuasan kerja melalui sistem E-Procurement secara parsial tidak mempunyai pengaruh signifikan terhadap kinerja karyawan, hal ini menandakan bahwa sistem E-Procurement tersebut setelah 
diterapkan, kepuasan kerja melalui sistem E-Procurement secara parsial tidak cukup signifikan terhadap kinerja karyawan, dalam arti sistem $E$ Procurement dan kinerja karyawan secara parsial pada Kompartemen Pengadaan belum mempunyai pengaruh dan kontribusi. Mungkin karena kekecewaan dari karyawan terhadap sistem E-Procurement yang sering mengalami kendala dan hambatan pada waktu jam operasional.

\section{Kesimpulan}

Dari hasil penelitian dan berbagai analisa olah data dapat disimpulkan sebagai berikut :

1. Sistem E-Procurement belum terlihat kontribusi signifikan terhadap kinerja karyawan.

2. Terdapat peningkatan efisiensi kerja melalui sistem $E$ Procurement ini, walaupun terlihat minim.

3. Tidak adanya kepuasan kerja, terutama persepsi karyawan terhadap sistem E-Procurement.

Saran-saran untuk penelitian selanjutnya :

1. Agar dapat dicari faktor-faktor penyebab kepuasan kerja cenderung tidak berubah, walaupun sudah ada teknologi terbaru yang berdasarkan perkembangan teknologi informasi, yaitu sistem $E$ Procurement .

2. Kemungkinan perlu dicari penyebab masalah mengapa sistem E-Procurement masih terjadi kendala dan hambatan operasional terutama di jam kerja.

\section{Referensi}

Arikunto, S. 2012. Prosedur Penelitian. Jakarta: Rineka Cipta.
Arikunto, Suhardjono, dan Supardi. 2011. Penelitian Tindakan Kelas. Jakarta: PT Bumi Aksara.

Armstrong, M. and Baron, A. 1998. Performance Management - The New Realities. London: Institute of Personnel and Development.

Bambang Supomo dan Nur Indriantoro, 2002, Metodologi Penelitian Bisnis, Cetakan Kedua, Yogyakara; Penerbit BFEE UGM.

Hasibuan, M. 2001. Manajemen Sumber Daya Manusia . Jakarta: Bumi Aksara.

Keith, D., \& W, J. 1995. Perilaku Dalam Organisasi Edisi Ketujuh. Jakarta: Erlangga.

Miraza, Bachtiar, 2004. Manajemen Bisnis, ISEI, Bandung.

Robert, D. 1993. Statistical Models For Casual Analysis . USA: Wiley, John \& Sons.

Sedamaryanti. 2001. Sumber Daya Manusia dan Produktivitas Kerja. Bandung : Mandar Maju.

Sugiyono. 2013. Metode Penelitian Pendidikan Pendekatan Kuantitatif, Kualitatif dan R\&D. Bandung: Alfabeta.

Syamsi, I. 2004. Efisiensi, Sistem dan Prosedur Kerja. Jakarta : PT. Bumi Aksara.

Walizer, M., \& Wienir, P. 1987. Metode dan Analisis Penelitian; Mencari Hubungan Jilid 2. Jakarta: Erlangga. 